1952 konnte er nach Westdeutschland zurückkehren und erhielt zunächst eine kümmerlich honorierte, sagen wir, "Hilfsdozentur" in Bonn. Zunächst sich recht bescheiden durch Expertisen über Wasser haltend, erhielt er für 4 Jahre ein Ordinariat für Lagerstättenkunde an der Bergbaufakultät in Istanbul. Inzwischen hatten aber die Bemühungen von K. Scheumann und A. Neuhaus den Erfolg, daß für ihn eine Art Sonderprofessur in Bon $n$ geschaffen wurde. Hier hat er die Mineralienund Lagerstättensammlung hervorragend aufgebaut, seine vielen Beziehungen wie seine Freiberger Erfahrungen in gleicher Weise nutzend. - Er hat der Bonner Universität dann noch bis zu seinem 85. Lebensjahr viele Dienste geleistet und dort noch viel Befriedigung und nach dem so bewegten Leben Ruhe gefunden, bevor er sich mit etwa 87 endgültig zur Ruhe setzte.

\title{
P. Ramdohr
}

\section{Information}

The WORLD PHOSPHATE ROCK INSTITUTE celebrates its second year.

It was in December 1973, during the Constitutive Meetings in Rabat and Tampa/ Florida, that the hopes of its promoters - conscious of the need to create a specialised organization, able to set up scientific and technical studies to promote the use of phosphate - were fulfilled

Eleven producing companies mining in Algeria - Brazil - the States Jordan - Morocco - Senegal - Syria - Togo - Tunisia, accounting for about half of the world production and three-quarters of its exports, were the first members.

It $\mathbf{s}$ aims

- to promote and encourage theoretical, technological and practical research concerning the various uses of rock phosphate

- to improve and develop its actual uses, particularly in agriculture and thus

- to contribute to the struggle against world hunger, through improved agricultural techniques and popularization of the most effective procedures for soil enrichment, especially in developing countries

- to define and develop new usages.

A permanent Secretariat, established in Paris, at 8, rue de Penthievre, handles the administrative activity, organizes the meetings and coordinates the work. 